\title{
Pemberdayaan Pendidikan di Madrasah (Studi Kasus Pada Madrasah Ibtidaiyah Nelayan Suku Laut Kuala Tungkal)
}

\author{
M. Syahran Jailani \\ Universitas Islam Negeri Sulthan Thaha Safuddin Jambi \\ m.syahran@uinjambi.ac.id
}

DOI. 10.18860/mad.v12i2.9599

Abstract: This study is aimed at revealing how is the empowerment of education at Madrasah Ibtidaiyah in Fisherman village Suku Laut Kuala Tungkal. Madrasah are generally born from the initiation of society as a form of concern for the condition of the people, especially children in understanding the special religion of Islam as a matter of doubt. This research is conducted by using qualitative approach. Research result, Islamic schools gait has contributed greatly to this country not only in providing a religious understanding, but also in participating to educate the children of the nation through the educational process that has lasted tens or even hundreds of years. In its journey, the empowerment of Islamic schools experienced various dynamics, commitment of Islamic school leadership, public awareness and supporting efforts became the issue that made Islamic schools hard to develop as expected.

Keywords: Empowerment of madrasah, management, and society.

\begin{abstract}
Abstrak: Penelitian ini bertujuan untuk mengungkap bagaimana pemberdayaan pendidikan di Madrasah Ibtidaiyah Nelayan Suku Laut Kuala Tungkal. Madrasah umumnya lahir inisiasi masyarakat sebagai bentuk keprihatinan terhadap kondisi umat terutama anak-anak dalam belajar agama, khusus Islam sebagai sebuah keyaqinan. Penelitian ini dilakukan dengan pendekatan kualitatif. Temuan penelitian mengungkap bahwa, kiprah madrasah telah memberi konstribusi besar untuk negeri ini tidak hanya memberi pemahaman keagamaan, akan tetapi turut serta mencerdaskan anak-anak bangsa melalui proses pendidikan yang telah berlangsung puluhan bahkan ratusan tahun lamanya. Dalam perjalananya, pemberdayaan madrasah mengalami berbagai dinamika, komitmen kepemimpinan madrasah, kesadaran masyarakat dan daya dukung menjadi persoalan yang turut menjadikan Madrasah Ibtidaiyah pada Nelayan Suku Laut Kuala Tungkal belum berkembang sebagaimana diharapkan.
\end{abstract}

Kata Kunci: Pemberdayaan madrasah, pengelolaan dan masyarakat.

Received : 15-06-2020

Approved : 28-06-2020

Revised : 27-06-2020

Published : 30-06-2020

Copyright (C) Madrasah Jurnal Pendidikan dan Pembelajaran Dasar. All Right Reserved.

This is an open access article under the CC BY-NC-ND license

(http://creativecommons.org/licenses/by-nc-nd/4.0/).

Correspondence Address: m.syahran@uinjambi.ac.id

\section{A. PENDAHULUAN}

Penyelenggaraan pendidikan dalam suatu negara dan bangsa yang maju, unggul, dan berkualitas serta bermartabat, karena negara menempatkan pendidikan sebagai prioritas pembangunan sumber daya manusia. Soedijarto (2008: 11) menyebut, pendidikan atau yang lebih luas pembangunan sumber daya manusia merupakan unsur paling strategis bagi pembangunan negara bangsa. Langgulung (1986) secara tegas menyatakan bahwa "Maju mundurnya kebudayaan dan peradaban suatu bangsa sangatlah ditentukan seberapa besar akses pendidikan bagi masyarakat secara keseluruhan". Novak (1986: 18) menyatakan bahwa "education is an area of work through 


\section{MADRASAH}

Jurnal Pendidikan dan Pembelajaran Dasar

p ISSN: 1979-5599 | e ISSN: 2502-194X

P a g e | 155

which one can hope to improve the quality of life". Mengangkat dan memperoleh derajat dalam kehidupan manusia tersebut, manusia tidak dengan serta merta tumbuh dan berkembang dengan sendirinya dan dilalui tanpa proses. Proses panjang yang dilalui seorang individu (manusia) tersebut dinamakan dengan " proses pendidikan".

Madrasah dengan misi, tugas serta fungsi yang sama seperti lembaga pendidikan lainya, tidak hanya sekedar transfer pengetahuan kepada peserta didik (anak). Lebih dari itu madrasah sebagai lembaga pendidikan juga memberi kontribusi edukasi dan sosial kepada masyarakat dan anak-anak, serta pembinaan generasi penerus yang memiliki kekuatan nilai-nilai keyakinan beragama yang ditunjukkan melalui perilaku keseharian. Misi dan tugas mulia madrasah sebagai lembaga pembentukan akhlak peserta didik diyakini akan mampu menjadi misi da'wah baik diri pribadi, keluarga mapun masyarakat luas, sebagaimana dikemukakan Abdul Rachman Shaleh (2005: 20) "madrasah mempunyai karakter yang spesipik bukan hanya melaksanakan tugas pendidikan dan pengajaran agama, tetapi juga mempuyai tugas untuk memberikan bimbingan hidup". Oleh karena itu madrasah adalah milik masyarakat dan menyatu dengan nilai-nilai yang telah hidup dan dikembangkan di dalam kebudayaan sebagai milik masyarakat.

Secara tegas Undang-undang Sistem Pendidikan Nasional nomor 20 tahun 2003 Bab III Pasal 4, menyatakan bahwa; (1) pendidikan diselenggarakan secara demokratis dan berkeadilan serta tidak diskriminatif dengan menjunjung tinggi hak asasi manusia, nilai keagamaan, nilai kutural, dan kemajemukan bangsa, (2) pendidikan diselenggarakan sebagai satu keasatuan yang sistemik dengan sistem terbuka dan multimakna, (3) pendidikan diselenggarakan sebagai suatu proses pembudayaan dan pemberdayaan peserta didik yang berlangsung sepanjang hayat, (4) pendidikan diselenggarakan dengan memberi keteladanan, membangun kemauan, dan mengembangkan kreativitas peserta didik dalam proses pembelajaran, (5) pendidikan diselenggarakan dengan mengembangkan budaya membaca, menulis, dan berhitung bagi segenap warga masyarakat, dan (6) pendidikan diselenggarakan dengan memberdayakan semua komponen masyarakat melalui peran serta dalam penyelenggaraan dan pengendalian mutu layanan pendidikan.

Hari ini, masih ada anggapan sebagian masyarakat memandang pendidikan di Madrasah Ibtidaiyah belum memberikan banyak harapan, misalnya: lulusan akan sulit diterima di sekolah favorit, kualitas dipertanyakan, orang tua lebih memilih memasukan anak ke Sekolah Dasar Negeri ketimbang Madrasah Ibtidaiyah, di madrasah berbayar, semenatara di Sekolah Dasar Negeri tidan pakai SPP bahkan ada bantuan dan lain sebagainya, bahkan madrasah dipandang sebelah mata, dan lembaga pendidikan kelas dua.

Perkampungan Masyarakat Nelayan Suku Laut Kuala Tungkal, di samping memiliki tiga buah Sekolah Dasar Negeri (SDN), terdapat pula lembaga pendidikan Islam yang dikelola oleh msayarakat setempat. Yaitu, dua buah Madrasah Ibtidaiyah dan tiga buah Taman Bacaan Al-Qur'an. Khusus dua Madrasah Ibtidaiyah Tarbiyah Islamiyah yang berjumlah siswa/siswi (santri) 185 orang. 100 orang berasal dari anakanak Suku Laut. Sementara pada Madrasah Ibtidaiyah Jauharul Ihsan memiliki siswa/siswi (santri) 60 orang yang sebagian besar anak anak di luar Suku Laut Kuala Tungkal (Data: kelurahan Tungkal II, 2018). Fasilitas sarana dan prasarana gedung 
sangat jauh dari kata layak, gaji atau reward semata-mata hanya mengandalkan SPP dari siswa/siswi dan hanya diberikan bila siswa-siswi membayar tepat waktu, support para orang tua belum maksimal mendampingi anak-anak dalam belajar agama akibat disibukkan orang tua bekerj asebagai nelayan.

Fenomena di atas, menarik perhatian penulis mengkaji lebih dalam tentang "Pemberdayaan di Madrasah (Studi masyarakat Nelayan Suku Bajau Kuala Tungkal)", dengan fokus penelitian, sebagai berikut: "Mengapa masyarakat nelayan Suku Laut Kuala Tungkal belum menjadikan madrasah sebagai tempat untuk memperoleh pembelajaran yang berkualitas" ?

\section{B. METODE PENELITIAN}

Penelitian ini dilakukan dengan menggunakan pendekatan kualitatif. Pendekatan kualitatif dilakukan dalam rangka menemukan "kebermaknaan", dengan pendekatan menggunakan Langkah-langkah pemikiran Spradley (1980). Pengambilan sampel dalam penelitian ini mengacu pada kreteria yang gunakan Spradley (1980), yaitu: (1) subjek yang telah cukup lama dan intensif " menyatu" dengan suatu kegiatan atau "medan aktivitas" yang menjadi sasaran perhatian penelitian; (2) subjek yang masih terlibat secara penuh/aktif pada lingkungan kegiatan yang menjadi sasaran/perhatian penelitian; (3) subjek yang mempunyai cukup banyak waktu atau kesempatan untuk diminta informasi; (4) subjek yang dalam memberikan informasi tidak cendrung "diolah" atau "dikemas" terlebih dahulu; dan (5) subjek yang sebelumnya tergolong masih "asing" dengan peneliti sehingga dapat merasa lebih tertantang untuk "belajar" sebanyak mungkin dari subjek yang semacam guru baru bagi dirinya. Bila berpedoman pada kretria di atas, maka yang menjadi subjeknya yaitu: Kepala madrasah, guru, siswa/siswi, orang tua dan tokoh Agama atau tokoh masyarakat.

Metode pengumpulan data yang digunakan dalam penelitian ini sebagimana yang disarankan Denzin dan Lincoln (2009: 525), yaitu observasi, wawancara, dokumentasi dan menggunakan sumber non manusia, serta pencatatan hasil pengumpulan data. Didukung pula oleh interaksi langsung dengan subjek peneliti seperti, mendengarkan, melihat, berbicara, bertanya, meminta penjelasan, mengekspresikan dan menangkap isyarat yang tersirat dari subjek yang terlibat. Untuk uji keabsahan data, merujuk Lincoln dan Guba (1985: 328-332), menyarankan agar menggunakan, yaitu: (1) standar kredibilitas; (2) standar tranferbilitas; (3) standar dependabilitas; dan (4) standar konfirmabilitas.

\section{HASIL DAN PEMBAHASAN}

Secara Geografis Nelayan Suku Laut Kuala Tungkal berada pada posisi $0^{\circ} 45$ $1^{\circ} 27$ Lintang Selatan (LS) dan $102^{\circ} 38$ - $104^{\circ} 33$ Bujur Timur. Dengan luas wilayah Tungkal II $\pm 1.080 \mathrm{Ha}$, dari keseluruhan luas wilayah Kecamatan Tungkal Ilir yang meliputi \pm 320.100 Ha. Berjarak 125 KM dari Ibu ota Provinsi Jambi atau 1440 KM dari Ibu Kota Republik Indonesia Jakarta. Dilihat dari topografi, perkampungan nelayan yang berada di Kelurahan Tungkal II, terletak pada dataran rendah berawa-rawa dan tanah lumpur yang ditumbuhi pohon bakau, pohon nipah dan pohon api-api. Dengan kategori daerah pasang surut yang biasanya terjadi dua kali selam 24 jam. Air pasang besar terjadi di bulan Desember- April. Berada di bibir pantai dengan letak ketinggian 0-2,5M dari permukaan laut. Perkampungan nelayan Suku Laut Kuala Tungkal termasuk daerah subtropis yang umumnya beriklim lembab/basah, dimana curah 


\section{MADRASAH}

Jurnal Pendidikan dan Pembelajaran Dasar

p ISSN: 1979-5599 | e ISSN: 2502-194X

P a g e | 157

hujan hampir merata sepanjang tahun yaitu 2.000-3000 $\mathrm{M}^{3}$ dengan suhu rata-rata $23{ }^{\circ} \mathrm{C}$ dan maksimum $32{ }^{\circ} \mathrm{C}$.

Jumlah penduduk Kelurahan Tungkal II 8.792 orang. Dari jumlah keseluruhan penduduk kecamatan Tungkal Ilir berjumlah 111.694 jiwa. Dari 8.792 penduduk Tungkal Ilir, 4.362 laki-laki dan 4.430 orang perempuan. Sementara jumlah penduduk Khususnya dari Suku Laut Kuala Tungkal berjumlah 400 jiwa atau 177 kepala keluarga.

Tabel C.1 Data Penduduk Kelurahan Tungkal II

\begin{tabular}{ccc}
\hline Laki-laki & Perempuan & Jumlah \\
\hline 4.362 Orang & 4.430 Orang & 8.792 Orang \\
\hline
\end{tabular}

Sumber: Monogram Kelurahan Tungkal II, tahun 20118

Menurut data kependudukan KelurahanTungkal II, penduduk perkampungan nelayan berada di empat Rukun Tetangga (RT), yaitu RT. 001, RT. 009, RT. 17, dan RT. 003.

Tabel C.2 Data Penduduk Suku Laut menurut jenis kelamin.

\begin{tabular}{cccc}
\hline No & Jenis Kelamin & Orang & Persentase \\
\hline 1 & Laki - laki & 193 & $48,3 \%$ \\
\hline 2 & Perempuan & 207 & $51,7 \%$ \\
\hline 3 & Jumlah & 400 & $100 \%$ \\
\hline
\end{tabular}

Sumber: Informasi Sekretaris Lurah Tungkal II, tahun 2018

Umumnya penduduk nelayan Suku Laut yang berada di Kuala Tungkal, hidup berkelompok-kelompok mendiami sepanjang pesisir pantai sungai pengabuan yang berhadapan langsung dengan selat Berhala dan Laut China Selatan. Menurut salah seorang tokoh masyarakat Suku Laut pak AB, mengemukakan sebagai berikut :

"Sebelum kami bermukim dan menetap di darat, dahulu kami ini hidup dan tinggal di perahuperahu besar maupun kecil sesuai dengan ukuran keluarga. Perahu yang kami gunakan itu dinamakan perahu "dekang" yang terdiri dari tiga bagian. Bagian depan perahu biasanya tempat tinggal anak-anak, bagian tengah tempat tidur yang terdiri dari kamar tidur anak-anak dan orang tua, bagian belakang biasanya tempat memasak dan tempat peliharaan binatang seperti burung, kucing dan hewan peliharaan lainnya. Baru tahun 1920-an, Suku kami mulai menetap dan bermukim di darat. Dengan pertimbangan tetap tidak jauh dari laut. Sebenarnya istilah "Bajau" menurut orang kami Suku Laut bukanlah istilah nama yang pantas di berikan kepada kami, karena orang kami Suku laut sendiri tidak menyebut dengan istilah Bajau, Istilah Bajau sendiri di berikan kepada masyarakat lain di luar Suku laut. Orang kami Suku Laut sendiri menyebut Suku Laut dengan sebutan "Suku Dono atau Duano". Artinya penduduk yang berpindah-pindah. (Wawancara Minggu, tanggal 13 Februari 2018. Pukul. 16..00 Wib).

Berdasarkan hasil laporan peneltian STAIS An-Nadwah Kuala Tungkal tahun 1992. Sebagaimana dikutip dalam buku "Studies in Moro History, Law and Religion" dikarang Juan. G. F Zaide terbitan tahun 1991. Menjelaskan sejarah asal-usul penduduk Suku Laut Kua Tungkal, sebagai berikut: "Pada tahu 1380 M, Islam mulai masuk ke Philipina yang dibawa oleh seorang mubaligh dari negeri arab bernama "Mak Dum". Kemudian pada tahun 1390 M misi da'wah disusul oleh Rajo Bagindo dari Minangkabau Sumatera Barat. Selanjutnya, pada tahun $1450 \mathrm{M}$ seorang mubaligh berasal dari Palembang bernama Abu bakar berhasil memasuki kepulauan Sulu 
(Selatan Fhilipina) mengembangkan dan menda'wahkan syiar Islam selama puluhan tahun. Pada tahun 1475 M, seorang saudagar Arab bernama Syarif Kebungsuan menikah dengan Putri Tumina di pulau Mindanau selatan Fhilipina, dan pada akhirnya beliau menjadi raja di kesulthanan Miindanau dan sekitarnya. Dari pulau Sulu dan Mindanau, Islam melebarkan syiarnya sampai kekepulauan Luzon ke utara Philipina yang berbatasan dengan pulau Sulawesi. Dan akhirnya pada tahu $1571 \mathrm{M}$, untuk pertama kalinya kerajaan Islam berdiri di Philipina di bawah kekuasaan seorang raja berna Sulthan Sulaiman.

Pada tahun 1569 M, bangsa Spanyol (Eropa) datang ke Philipna yang mulanya hanya sekedar singgah. Karena alam yang subur dan potensi kekayaan serta posisi yang strategis, lama-kelamaan bangsa Spanyol memiliki hasrat ingin menguasai. Apa lagi ketika itu bangsa Philipina khususnya kota Manila yang mayoritas Islam, masih sangat sedehana dan belum begitu maju dalam peradaban. Infasi pun terjadi dan perang tak dapat dihindarkan, bangsa Spanyol menjajah dan merampas semua hak-hak rakyat Philipina dan sekitarnya, perang dahsat memakan waktu cukup panjang hampir selama lebih dari 300 tahun. Tahun $1876 \mathrm{M}$ di lanjutkan oleh Amerika yang sempat menjajah wilayah Philipina dan berakhir tahun $1914 \mathrm{M}$. Akibat di jajah beratus tahun lamanya, bangsa Spanyol di samping menguasai potensi alam juga melakukan misi penyebaran Agama. Rakyat Philipina di paksa untuk beralih agama yang semula beraga Islam pindah ke agama Katholik. Akibatnya banyak penduduk Philipina yang mencari perlindungan dengan cara melarikan diri dengan berlayar ke pulau-pulau terdekat ke selatan Philipina seperti Moro, Mindanau, Sulu dan Zamboanga. Sebagian lagi ada yang melarikan diri dengan berlayar berhari-hari samapai akhirna menetap ke kepulauan Sulawesi, Kalimantan, bahkan ada sampai ke pulau Sumatera terutama di pesisir pantai timur Sumatera, seperti Kepulauan Riau, Sumatera Selatan bahkan Kuala Tungkal (Jambi)".

Diantara kehidupan sosial budaya masyarakat perkampungan nelayan Suku Laut Kuala Tungkal yang masih kuat dipertahankan adalah kebiasaan sebelum ke laut, yaitu dengan melakukan kegiatan ritual berupa do'a dengan diselingi kemenyan sebagai syarat agar terhindar dari musibah atau terhindar dari bahaya di laut dan ketika pulang dari melaut selamat sampai ke rumah. Menghindarkan diri dari pantangan-pantangan seperti larangan membawa bakul (terbuat dari rotan), dilarang berkata kotor disaat melaut, atau melakukan tindakan tidak terpuji. Bila itu dilakukan, biasanya hasil tangkapan tidak membuahkan hasil yang diharapkan. (Dokumentasi, Agustus 2018)

Jika dilihat dari karakteristik bentuk tubuh/fisik, terlihat cir-ciri khusus penduduk perkampungan nelayan Suku Laut, misalnya warna kulit kehitam-hitaman, bentuk kaki baik laki-laki atau perempuan berbentuk $\mathrm{O}$, dan berjalan agak membungkuk, pinggul lebih menonjol, bentuk wajah pada gigi geraham menonjol kedepan, telapak kaki lebar dan antara ujung kaki dengan tumit hamper rata. Kebiasaan lain yang agaknya sulit dirobah dari perkampungan nelayan dan khususnya Suku Laut adalah kebiasaan berbicara keras. Bagi kita yang baru bertemu mereka, dengan melihat mereka berbicara seolah-olah bereka sedang bertengkar atau sedang berkelahi. (Observasi. Pukul 16.0017.00. Maret 2018)

Umumnya masyarakat perkampungan nelayan khususnya masyarakat Suku Laut Kuala Tungkal, dari hasil pengakuannya status beragama Islam, ini terlihat dari kartu tanda penduduk (KTP) yang tertera. Dari hasil pengamatan peneliti di lapangan, 


\section{MADRASAH}

Jurnal Pendidikan dan Pembelajaran Dasar

p ISSN: 1979-5599 | e ISSN: 2502-194X

menunjukkan bahwa status mereka beragama Islam tidak di barengi dengan pengamalan agama sebagaimana dikehendaki ketentuan syariat. Praktek-praktek keagamaan (Islam) tidak dijalankan, misalnya ketika tiba waktu shalat zhuhur, shalat ashar, atau shalat magrib tidak dilaksanakan. Mereka sibuk dengan aktivitas masingmasing. Kalaupun ada kegiatan keagamaan hari besar Islam seperti kegiatan Isra' mi'raj, maulid Nabi Muhammad SAW, atau kegiatan tahun baru Islam dengan menghadirkan da'i (penceramah) dari luar kota/dalam kota hanya sedikit sekali datang. Di lokasi perkampungan nelayan ini terdapat tiga mesjid/langgar, kebanyakan yang mengisi waktu shalat lima waktu, justru penduduk di luar Suku laut. Dengan pengetahuan keagamaan yang terbatas, tidak didukung pemahaman keagamaan yang cukup, membuat kebanyakan dari mereka orang tua jauh dari pengamalan agama yang mestinya dilakukan. Sangatlah beralasan kemudian, apabila anak-anak mereka juga sangat jauh dari pengamalan keagamaan, ini terlihat dari pengamatan penulis ketika mengunjungi salah satu Taman Pengaji Al-Qur'an (TPA) Hidayatus Shobiyah, dari lima puluhan anak usia 0-6 tahun, anak 6-12 tahun belajar mengaji hanya 3-5 orang saja anak dari penduduk Suku Laut selebihnya anak-anak di luar Suku Laut.

Suasana dalam keluarga, sangat mempengaruhi kehidupan keagaman dan pergaulan anak-anak. nilai-nilai agama yang semestinya dapat diterima anak-anak sejak dini tidak terjadi, dan kondisi ini di perparah dengan lingkungan sekitar pemukiman penduduk tidak kondusif untuk menunjang proses pendidikan anak-anak. Misalnya, terdapat tempat permainan bola bilyar yang mestinya menurut aturan tidak boleh ada di sekitar pemukiman penduduk. permainan kartu domino yang dilakukan orang-orang dewasa yang lokasinya berdekatan dengan rumah penduduk, yang secara tidak langsung terlihat oleh anak-anak.(Observasi, Pukul 16.00-17.30. Maret 2018)

Keberadaan Madrasah Ibtidaiyah di lokasi nelayan Suku Laut Kuala Tungkal sangat membantu para orang tua dalam ikut serta mencerdaskan anak-anak bangsa , meskipun disekitar lokasi perkampungan nelayan Suku Laut Kuala Tungkal telah berdiri Sekolah Dasar Negeri misalnya: Sekolah Dasar Negeri 14/V, Sekolah Dasar Negeri 24/V dan Sekolah Dasar Negeri 190/V Kuala Tungkal, namun tidak mengurangi niat dan i'tikad para tokoh agama dan tokoh masyarakat untuk mendirikan madrasah, terutama madrasah ibtidaiyah. Hal ini tidak terlepas dari keinginan kuat para tokoh agama dan tokoh masyarakat yang mngingingkan agar anak-anak di sekitar perkampungan nelayan memiliki pengetahuan agama yang cukup untuk masa depan anak-anak dikemudian hati. Pengakuan ini peneliti peroleh melalui wawancara bersama tokoh masyarakat seperti H. S. A (70 tahun) menyatakan bahwa:

"kehadiran madrasah di perkampungan nelayan ini awalnya untuk mengantisipasi banyaknya anak-anak disini yang belum mampu membaca al-Qur'an dan menulis Arab melayu, dan biasanya pada sore hari anak-anak ini lebih banyak bermain yang saya nilai kurang bermanfaat. Maka atas inisiatif tokoh masyarakat dan tokoh agama diantaranya dulu ada tokoh agama dikalangan Suku Laut bernama uztaj AA, bersepakat mendirikan madrasah agar anak-anak tau dan faham dengan Islam dan berharap dikemudian hari anak-anak ini dapat menjalankan ajaran agama secara benar ( Wawancar. Tanggal 12 Maret 2018 Pukul: 17.00 Wib).

Dalam perjalanannya, madrasah Ibtidaiyah Tarbiyah Islamiyah kampung nelayan Kuala Tungkal mengalami perkembangan yang cukup baik terutama diawalawal berdiri tahun 1970-an, dan mengalami kemunduran beberapa tahun kemudian diakibatkan diantaranya, yaitu: (1) sistem kepemimpinan madrasah yang masih 
menganut faham ewuh pakewuh di kalangan guru-guru (uztaj/uztajah) yang tetap mempertahankan kepala madrasah berdasarkan senioritas (guru tua) meskipun dari segi visioner dan prospektif tidak mengalami perubahan baik dari kualitas lulusan maupun pengembangan madrasah, meskipun dari kuantitas para santri melebihi kapasitas daya tampung ruang belajar, (2) pengembangan madrasah belum mendapatkan dukungan nyata dari pihak-pihak terkait, misalnya: minimnya bantuan bangunan ruang belajar dari Kementerian Agama Kabupaten dan Provinsi, pemerintah kabupaten, dan tidak adanya bantuan dari badan usaha milik swasta yang berinvestasi disekitar perkampungan nelayan, dan (3) kompetensi para guru yang mengabdikan diri sebagai tenaga pendidik umumnya dari tamatan lulusan madrasah Aliyah dengan niat keikhlasan beramal, meskipun jika ada honororium tidak sebanding dengan pekerjaan sebagai pendidik.

Madrasah Ibtidaiyah Tarbiyah Islamiyah Nelayan Suku Laut Kuala Tungkal satu diantara madrasah yang menyelenggarakan proses pembelajaran dengan pendekatan pembelajaran yang biasa umumnya digunakan di madrasah-madrasah yang ada di Indonesia, misalnya menggunakan kitab-kitab arab melayu, menghafal ayat-ayat dalam surah pendek, dan tidak menggunakan kurikulum nasional yang berlaku di Sekolah yang dikelola Kementerian Pendidikan Nasional. Artinya, kurikulum yang digunakan menggunakan kurikulum semi pondok pesantren, meskipun tidak semua menggunakan model pesantren. Hasil wawancara salah seorang uztaj bernama $\mathrm{AB}$ mengungkapkan sebagai berikut:

"Kurikulum yang digunakan di madrasah Tarbiyah Islamiyah berpedoman pada kurikulum pondok pesantren yang umumnya digunakan pesantren-pesanten yang ada di Kuala Tungkal, meskipun tidak semuanya materi pelajaran menggunakan kurikulum pondok pesantren. Hal ini bisa dilihat dari kitab-kitab yang digunakan guru (uztaj/uztajah), misalnya: kitab figh dalam bahasa arab melayu, kitab tauhid dalam bahasa arab melayu, dan kitab matan jurmiah, ilmu sharaf Tasyriful wadhi' dan lain-lain. (Wawancara. Tanggal 19 Maret 2018. Pukul 16.30 Wib).

Kepemimpinan madrasah Tarbiyah Islamiyah perkampungan nelayan Kuala Tungkal mengacu pada tradisi/model kepemimpinan pesantren ummunya yaitu menempatkan guru (uztaj) yang menguasai pengetahuan agama yang mendalam dan lebih senior dari segi usia maupun pengalaman mengajar. Meskipun model/tradisi ini telah berlangsung cukup lama dari satu kepemimpinan ke pimpinan lainnya, namun aspek pemberdayaan madrasah belum membawa perubahan yang berarti. Misalnya: pemberdayaan guru-guru (uztaj/uztajah) yang belum dimaksimalkan dengan baik, msekipun diantara guru-guru (uztaj/uztajah) memiliki keahlian/keterampilan lain selain mengajar, seperti: keterampilan menulis kaligrafi, berjanji nazhom, atau keterampilan membaca ayat-ayat al-Qur'an. Mestinya, keahlian para guru-guru (uztaj/uztajah) menjadi daya tarik madrasah Tarbiyah Islamiyah untuk menggait dan menarik anak-anak untuk masuk ke madrasah.

Hasil temuan penelitian menemukan bahwa beberapa faktor yang mempengaruhi madrasah belum menjadikan tempat yang menjadi favorit (senang) untuk belajar menuntut ilmu diantaranya, yaitu sebagai berikut, yaitu: (1) Pandangan (persepsi) orang tua tentang madrasah. Umumnya para orang tua beranggapan sekolah di SD lebih memberikan kemudahan terutama dari segi biaya, karena di sekolah dasar anak-anak tinggal masuk dan bebas biaya, bahkan sekolah dapat bantuan dari pemerintah, (2) sosialisasi dan promosi madrasah. Meski pun madrasah sudah ada sebelum sekolah dasar didirikan, ketertarikan anak-anak untuk belajar dimadrasah terasa belum menjadi kebanggaan bagi para orang tua diperkampungan nelayan Kuala 


\section{MADRASAH}

Jurnal Pendidikan dan Pembelajaran Dasar

p ISSN: 1979-5599 | e ISSN: 2502-194X

P a g e | 161

Tungkal, di samping persepsi orang tua yang masih memandang belajar di madrasah sebagai tempat yang belum menjamin masa depan. Pendekatan sosialisasi dan promosi madrasah sebagai tempat yang baik untuk menimba ilmu, tidak hanya ilmu keduniaan tetapi juga ilmu-ilmu yang berkaitan dengan keagamaan. (Wawancara. Salah seorang orang tua, Y. Maret 2018. Pukul 16.00-17.30).

\section{PEMBAHASAN}

Pemberdayaan madrasah yang konprehensif pada akhirnya akan melahirkan lembaga pendidikan dan sosok lembaga yang memiliki karakter yang kuat dan dibanggakan, tidak saja bagi kemimpinan Kepala Madrasah yang bersangkutan, tetapi juga membawa suasana pencerahan di tengah terpaan dan sorotan tajam yang luar biasa bagi keberadaan madrasah di Indonesia, khususnya dan perkembangan lembaga pendidikan di Indonesia umumnya, yang hari ini masih diliputi segudang problem begitu kompleksitas. Melihat sejarah lahirnya madrasah, dari masyarakat untuk masyarakat dan dikembangkan oleh masyaakat, tak dapat dimungkiri kehadirannya telah memberikan nilai konstribusi nyata bagi keberlangsungan pendidikan anak-anak bangsa. Masyarakat memberikan andil besar dalam mendorong lahirnya berbagai kelembagaan pendidikan di nusantara ini, hal ini terbukti dengan adanya pendidikan ala pesantren yang telah lebih dulu ada sebelum Indonesia merdeka. Suharto sebagaimana dikutip Azra (2005:329) menyebutkan, dikalangan masyarakat Muslim Indonesia, partisipasi masyarakat dalam rangka pendidikan berbasis masyarakat telah dilaksanakan lebih lama lagi, yaitu setua sejarah perkembangan Islam di Indonesia, mulai dari rangkang, dayah, meunasah, (Aceh), surau (Minangkabau), pesantren (Jawa), bustanul athfal, diniyah dan sekolah-sekolah Islam lainya didirikan dan dikembangkan oleh masyarakat muslim. Lembaga-lembaga ini hanya sekedar contoh bagaimana konsep pendidikan berbasis masyarakat diterapkan oleh masyarakat Indonesia dalam lintasan sejarah.

Madrasah merupaan isim makan dari kata "darasa" yang berarti "belajar". Jadi madrasah berarti tempat belajar bagi siswa atau mahasiswa (umat Islam). Dalam sejarah pendidikan Islam, makna dari madrasah tersebut memegang peranan penting sebagai institusi belajar umat Islam selama pertumbuhan dan perkembangannya. Sebab, pemakaian istilah madrasah secara definitif baru muncul pada bad ke-11. Penjelasan istilah madrasah merupakan transformasi dari mesjid ke madrasah, ada beberapa teori yang berkembang seputar proses transformasi tersebut antara lain George Makdis menjelaskan bahwa madrasah merupakan transformasi institusi pendidikan Islam dari mesjid ke madrasah terjadi secara tidak langsung melalui tiga tahap: Pertama, tahap mesjid. Kedua, masjid-khan; dan Ketiga, tahap madrasah (Nizar, 2009:120). Selanjutnya Nizar (2009: 120-121) mengemukakan bahwa, dilihat dari aspek historis, esksistensi madrasah baik pada abad klasik XXI (saat ini) tidak jauh berbeda. Dinamika madrasah yang tumbuh dan berakar dari kultur masyarakat setempat tidak akan luput dari dinamika dan peradaban masyarakat (change of society). Tidak salah kalau banyak mensinyalir bahwa madrasah tumbuh dan berkembang dari bawah ke atas . kenyataan ini, sering kali kita menemukan madrasah yang mati, namum tetap eksis dan sejalan dengan kehidupan masyarakat setempat, meskipun kehidupannya sangat stagnan. Menurut ahli sejarah berbeda pendapat tentang madrasah yang berdiri, walaupun ada beberapa pendapat yang cukup refresentatif. Ali al-Jumbulati 
sebagaimana dikutif Nizar (2009: 121) mengungkapkan bahwa sebelum abad ke-10 dikatakan madrasah yang pertama adalah al-Baihaqiyah di kota Nisabur. Disebut sebagai al-Baihaqiyah karena ia dirikan oleh Abu Hasan al-Baihaqi (w.414). Pendapat ini diperkuat hasil penelitian Richard Bullir (1972) yang menyatakan bahwa dua abad sebelum berdiriya Madrasah Nizamiyah telah berdiri madrasah di Nisabur, yaitu madrasah Miyan Dahiya yang mengajarkan Fiqih Maliki. Abd. Al-'Al (1977) menjelaskan bahwa pada masa Sulthan Mahmud al-Gasnawi (998-1030) telah berdiri madrasah Sa'diyah. Demikian juga Naji Ma'ruf (1973) berpendapat bahwa madrsah pertama telah didirikan 165 tahun sebelum Khurasan. Ia mengemukakan bukti di Tarekh al-Bukhari dijelaskan bahwa Ismail ibn Ahmad Asad (w.295) yang dikunjungi oleh para pelajar mereka. Syalabi dalam (Mehdi,2003) sebagaiman dikutip Nizar (2009) mengemukakan bahwa madrasah Perguruan Tinggi yang petama dibangun oleh AlJuwaini (w. 475/1063) dan Abu Qasim al-Qusyairi (w. 465/1072) adalah di Nisabur.

Madrasah sebagai salah satu institusi pendidikan Islam merupakan fondasi sekaligus prototipe dari kelanjutan sistem pendidikan Islam (madrasah) saat ini. Madrasah Nizam al-Muluk, misalnya adalah madrasah yang paling populer dikalangan ahli sejarah dan kalangan masyarakat Islam. Didirikan oleh Nizam alMuluk seorang Perdana Menteri Dinasti Salajikah pada masa pemerintahan Sulthan AlArsham dan Sulthan Maliksyah pada tahun ke-5 H/11 M yang diresmikan 459 H/1067 M. Pendapat Shaleh (2005: 11-12) mengemukakan bahwa, madrasah sebagai lembaga pendidikan dalam bentuk pendidikan formal sudah dikenal sejak awal abad ke-11 atau $12 \mathrm{M}$, atau abad ke-5-6 H, dikenal adanya madrasah Nidzamiyah yang didirikan di Baghdad oleh Nizam Al- Mulk seorang Wazir dari Dinasti Saljuk. Pendirian madrasah telah memperkaya khasanah lembaga pendidikan di lingkungan masyarakat Islam, karena pada masa sebelumnya masyarakat Islam hanya mengenal pendidikan tradisional yang diselenggarakan di mesjdi-mesjid dan dar al-hikmah. Di Timur Tengah institusi madrasah berkembang untuk menyelenggarakan pendidikan keislaman tingkat lanjut (advance/tinggi), yaitu melayani mereka yang masih haus ilmu sesudah sekian lama menimbanya dengan belajar di msejid-mesjid dan/atau dar al-khuttab. Dengan demikian, pertumbhan madrasah sepenuhnya merupakan perkembangan lanjut dan alamiah dari dinamika internal yang tumbuh dari dalam masyarakat Islam sendiri.

Menurut Shaleh (2005: 12), istilah madrasah di Indonesia merupakan fenomena modern yang muncul pada awal-awal abad ke-20. Berbeda dengan di Timur Tengah dimana madrasah adalah lembaga pendidikan yang memberikan pelajaran ilmu agama tingkat lanjut, sebutan madrasah di Indonesia mengacu kepada lembaga pendidikan yang memberikan pelajaran agaama Islam tingkat rendah dan menengah. Perkembangannya diperkirakan lebih merupakan reaksi terhadap faktor-faktor yang berkembang dari luar lembaga pendidikan yang secara tradisional sudah ada, terutama munculnya pendidikan modern barat. Dengan perkataan lain, tumbuhnya madrasah di Indonesia adalah hasil tarik menarik antara pesantren sebagai lembaga pendidikan asli (indegeus cultural/tradisional) yang sudah ada di satu sisi, dengan pendidikan Barat (modern) di sisi lain.

Kehadiran madrasah di Indonesia tidak terlepas dari sejarah masuknya agama Islam. Islam datang dibawa oleh pedagang-pedagang dari Gujarat,di syiarkan secara damai, tanpa paksaan, kekerasan dan perang. Proses penyebaran Islam dilakukan oleh pemuka agama yang telah mendalami Islam baik tatkala mereka belajar di Mekkah 


\section{MADRASAH}

Jurnal Pendidikan dan Pembelajaran Dasar

p ISSN: 1979-5599 | e ISSN: 2502-194X

P a g e | 163

maupun mereka para Wali yang telah mengembangkan Islam di Nusantara ini. Kehadiran para Wali-wali Allah yang menguasai ilmu agama tersebut menjadi suluh dan penerang bagi penduduk unuk mempelajari Islam secara benar. Penyebaran Islam secara damai dan tanpa paksaan menjadi sentuhan dan keyakinan yang kuat oleh masyarakat untuk mengetahui ajaran Islam yag sesungguhnya. Dan biasanya penduduk atau masyarakat mempelajari Islam melalui membaca, menulis dan megerjakan tata cara shalat di rumah-rumah, dilanggar, di mesjid-mesjid dan berkembang kemudian menjadi Pondok Pesantren.

Madrasah merupakan salah satu lembaga pendidikan yang statusnya berada dan bernaung di Kementerian Agama Republik Indonesia. Jauh sebelum bangsa Indonesia merdeka, madrasah-madrasah tersebut telah ada bahkan menjadi awal cikal bakal lahirnya lembaga-lembaga pendidikan Islam sejenis lainnya di Indonesia. Menurut Muhaimin, (2009: 77) salah satu corak pengembangan pendidikan sebelum Indonesia merdeka ialah bercorak isolative-tradisonal, dalam arti tidak mau menerima apa saja yang berbau barat (colonial) dan terhambatnya pengaruh pemikiran-pemikiran dalam Islam untuk masuk ke dalamnya, sebagaimana tampak jelas pada pendidikan pondok pesantren tradisional yang hanya menonnjolkan ilmu-ilmu agama Islam dan pengetahuan umum sama sekali tidak diberikan. Pondok pesantren yang merupakan lembaga pendidikan Islam adalah salah satu bentuk lain dari madrasah, jauh lebih dulu hadir sebagai wadah bagi umat Islam untuk belajar dan sebagai tempat untuk mendalami agama (Islam).

Keberadaan madrasah yang tersebar di penjuru bumi Nusantara ini, merupakan hasil insiasi warga masyarakat yang berupaya agar anak-anak mereka dapat memperoleh pendidikan yang layak dan mampu memberikan layanan maksimal terhadap pemenuhan pendidikan mereka, sehingga pada akhirnya anak-anak tersebut menjadi manusia yang berguna, bermanfaat bagi dirinya, keluarga dan bangsanya (Nizar, 2009). Akan tetapi tidak semua madrasah-madrasah yang ada di seluruh penjuru bumi Nusantara ini, telah dan bahkan mampu memberikan layanan dan kebutuhan yang yang menjadi harapan anak-anak, orang tua maupun stakeholder lainnya. Data statistik Kementerian Agama Republik Indonesia 2015, mencatat ada terdapat 72.726 lembaga madrasah. Dari jumlah 72.726 madrasah, hanya 9 persen yang dikelola pemerintah, sedangkan 91 persen dikelola masyarakat melalui yayasan atau melalui swadaya masyarakat. Dari 91 persen madrasah yang dikelola masyarakat, terus berkembang secara dinamis seiring dengan kebutuhan di masyarakat. Berbagai kebijakan yang dimiliki dengan dikeluarkannya PMA nomor 10 tahun 2010 Direktorat Pendidikan Madrasah sebagai payung hukum pengelola madrasah mesti berbasis analisis dinamika di tengah-tengah masyarakat. Dari sisi faktual historis sosiologis, madrasah adalah community based institusion. Hal ini searah dengan kebijakan dan amanah Peraturan Menteri Agama (PMA) nomor 10 tahun 2010 tentang Direktorat Pendidikan Madrasah (Ditpenma) untuk menjalankan tugas tidak boleh keluar dari sisi faktual historis dan sosiaologis madrasah. Artinya, Direktorat Pendidikan Madrasah harus senantiasa melihat dan inlne dengan dinamika yang berkembang. Diversifikasi atau penganekaragaman madrasah menjadi kata kunci untuk mengembangkan madrasah secara simultan (Menteri Kemenag RI, Media Indonesia. Jum'at, 5 Desember 2014). 
Menurut Shaleh (2005:159) mengemukakan bahwa, keberadaan madrasah merupakan wujud dari kesadaran teolog umat Islam guna menyiapkan generasi masa depan yang lebih baik. Semangat masyarakat untuk mendirikan madrasah biasanya akan selalu bergantung dengan tingkat kesadaran teologis masyarakat pendukungnya. Semangat sebagai khalifah fil Ardh dan kebutuhan untuk memperdaam dan mengamalkan jaran agamanya (tafaquh fiddin). Atas dasar kesadaran teologis tersebut umat Islam merasa memiliki beban wajib untuk mewujudkan pendidikan Islam yang baik serta menjaga kelestariannya. Selanjutnya kata Shaleh (2005) maju mundurya madrasah akan bergantung kepada seberapa besar kesadaran umat Islam mendukung madrasah dapat memilihara keberlangsungannya. Lembaga tersebut selain menjadi kekuatan penyebaran Islam juga berfungsi sebaga lembaga perguruan rakyat dalam rentang waktu lama telah melakukan upaya mencerdaskan kehidupan bangsa. Keadaan demikian walaupun di alam penjajahan Belanda, madrasa terus bertahan dan semakin kokoh, karena ditunjang oleh kekuatan besar, yaitu keasadaran teologis seerti disebutkan di atas pada satu sisi seta perhatian para Sulthan-Sulthan pada sisi yang lain.

Di dalam era reformasi sekarang ini, potensi daerah menjadi tumpuan dalam pembangunan, maka posisi madrasah dalam kesejarahannya adalah milik masyarakat harus dikembalikan seperti semula. Kementerian Agama harus berfungsi memberikan pelayanan, sepervisi, pengendalian, dan menjalankan kualitas kontrol, khususnya dalam pengembangan standar nasional pendidikan madrasah dan ciri khas keislaman dalam kehidupan yang serba mengglobal dan dunia tanpa batas. Aparat kementerian Agama di bidang pendidikan harus lebih banyak berfungsi sebagai pengendali dan pelayanan supervisi. Dengan demikian, madrasah tidak harus tampil dalam bentuk yang uniform dan tunggal untuk seluruh wilayah Indonesia. Madrasah pelu diberikan kesempatan untuk berkembang sejalan dengan aspirasi masyarakat lingkungannya. Kualitas hasil pendidikan madrasah akan dinilai oleh masyarakat. Demkian pula hidup matinya madrasah ditentukan oleh masyarakat itu sendiri (Shaleh, 2005: 163)

Posisi dan kedudukan madrasah dalam sistem pendidikan nasional diakui secara egaliter sebagai salah satu lembaga pendidikan yang turu serta berkonstribusi dalam mencerdaskan anak-anak bangsa, hal ini tertuang dalam pengumuman BPKNIP tertanggal 22 Desember 1945 (Berita RRI tahun II No.4 dan 5 halaman 20 kolom 1) menganjurkan agar: " dalam memajukan pendidikan dan pengajaran sekurang-kurangnya agar pengajaran dan pendidikan di langgar-langgar dan di madrasah berjalan terus dan diperpesat". Selanjutnya, pada tanggal 27 Desember 1945, BPKNIP menyarankan agar madrasah dan pondok pesantren mendapatkan perhatian dan bantuan material dari pemerintah, karena madrasah dan pondok pesantren pada hakikatnya adalah satu alat dan sumber pendidikan dan pencerdasan rakyat jelata yang sudah berakar dalam masyarakat Indonesia pada umumnya. Setelah berdirinya Departemen Agama tanggal 3 Januari 1946, di samping bertugas mengurus masalah-masalah agama, juga tugas pokoknya mengusrus masalah-masalah pendidikan agama di sekolah umum, dan masalah pendidikan di sekolah agama (madrasah dan pondok pesantren). Tugas pertama yang dijalankan adalah memberikan perbantuan kepada madrasah, dengan mengeluarkan Peraturan Menteri Agama nomor 1 tahun 1946 dan penyelenggaraan pendidikan agama di sekolah umum dengan mengeluarkan Peraturan Bersama Menteri PP \& K dan Menteri Agama nomor 1142/Bhg A (Pengajaran) tanggal 2-12-1946 dan 


\section{MADRASAH}

Jurnal Pendidikan dan Pembelajaran Dasar

p ISSN: 1979-5599 | e ISSN: 2502-194X

P a g e | 165

nomor 1285/K.J (Agama) tanggal 12-12-1946 yang berlaku efektif tanggal 1 Januari 1947.

Berdasarkan Keputusan Presiden nomor 136 tahun 1999 tentang struktur Organisasi Departemen Agama dan Keputusan Presiden nomor 49 tahun 2002 tentang kedudukan, fungsi, susunan organisasi dan tata kerja organisasi vertikal Departemen Agama. Adapun ruang lingkup pembinaan madrasah antara lain, meliputi: (1) mewujudkan ciri khas dan identitas madrasah sebagai satuan pendidikan yang mengembangkan kehidupan keberagamaan yang sarwa ibadah melalui program kegiatan antara sekolah, masyarakat, dan keluarga, (2) mengupayakan kemandirian manajemen dan pembiayaan pendidikan yan didukung oleh swadaya masyarakat.

Strategi pembinaan madrasah oleh Departemen Kementerian Agama, antara lain melalui program pencerahan madrasah, memiliki masa depan, madrasah yang berkualitas menjanjikan dan memasuki lapangan kerja dan melanjutkan sekolah, meliputi: (1) pembangunan madrasah model ( sebagai agen perubahan) yang mengajak madrasah sekitarnya untuk bersama-sama menjadi madrasah berkualitas. Yang dilengkapi fasilitas, seperti perpustakaan, laboratorium IPA, laboratorium bahasa, komputer, buku bahan ajar, dan ;lat peraga pendidikan, (2) madrasah terpadu, yaitu keterpaduan antara madrasah Ibtidaiyah, Tsanawiyah, dan Aliyah yang ditempatkan dalam satu lokasi. Keterpaduan dalam rangka keterpaduan administrasi, pengembangan kurikulum, pendayagunaan kelembagaan, penggunaan sarana dan fasilitas, serta pembiayaan pendidikan, dan (3) pemberdayaan (enpowering) madrasah dimaksudkan sebagai upaya agara madrasah tetap survive dan menjadi bagian dari sistem pendidikan nasional. Strategi pemberdayaan di maksud misalnya, program penuntasan wajib belajar 9 tahun. Upaya pemberdayaan madrasah dalam rangka school based management, serta upaya mengembangkan peran serta masyarakat dalam rangka tanggung jawab oleh orang tua dan masyarakat (community based management), di samping madrasah diharapkan pula agar merespon terhadap perubahan-perubahan yang terjadi, sehingga mewujudkan kondisi dinamis yang mampu menunjang upaya peningkatan mutu pendidikan di madrasah.

\section{KESIMPULAN}

Pemberdayaan Madrasah Ibtidaiyah yang dikelola dengan baik, akhirnya akan melahirkan lembaga pendidikan dan sosok lembaga yang memiliki karakter yang kuat dan dibanggakan, tidak saja bagi kemimpinan kepala msadrasah yang bersangkutan, tetapi juga membawa suasana pencerahan di tengah terpaan dan sorotan tajam yang luar biasa bagi keberadaan madrasah di Indonesia, khususnya dan perkembangan lembaga pendidikan di Indonesia umumnya, yang hari ini masih diliputi segudang problem begitu kompleksitas. Dalam rangka mendukung upaya pemberdayaan pendidikan di madrasah, maka keterlibatan masyarakat menjadi penting, mengingat stakeholder pendidikan adalah para orang tua yang memiliki anak. Oleh karena peran serta masyarakat dalam pendidikan pemilik utama madrasah, dalam Undang-undang Sistem Pendidikan Nasional nomor 20 tahun 2003 Bab XV Pasal 54 butir 1 dan 2 dengan tegas dinyatakan, bahwa: (1) peran serta masyaraka dalam pendidikan meliputi peran serta perseorangan, kelompok, keluarga, organisasi profesi, pengusaha, dan organisasi kemasyarakatan dalam penyelenggraan dan pengendalia mutu pelayanan pendidikan, 
(2) masyarakat dapat berperan serta sebagai sumber, pelaksana, dan pengguna hasil pendidikan.

\section{REFERENSI}

Abdul Rachaman Shaleh. (2005). Madrasah dan Pendidikan Anak Bangsa Visi, Misi dan Aksi . Jakarta: Raja Grafindo Persada.

Azyumardi Azra. (2000). Pendidikan Islam Tradisi dan Modernisasi Menuju Millenium Baru. Jakarta: Logos Wacana Ilmu

Adrian B. Lapian. (2009). Orang Laut, Bajak Laut dan Raja Laut. Jakarta: Komunitas Bambu.

Bogdan, Robert E. dan Taylor J. Steven. (1993). Kualitatif Dasar - Dasar Penelitian. (terjemahan A. Khosim Afandi) .Surabaya: Usaha Nasional.

Bogdan, Robert E. dan Bikland, Knopp.S. (1982). Qualitative Research For Education. Bostor : Allyn an Bacon Inc.

Berns, Robert. M. (2007). Child, Family, School, Community Socialization and Support. New York: Thomson Learning, Icn.

Denzin, Norman. K \& Lincoln, Yvonna.S. (1994). Handbook of Qualitatif Research. New York: Sage Publication, Inc.

Feinberg, Walter. (1986). School and Society. New York: Teacher College Press.

Francois. Robert Zacot. (2008). Orang Bajo Suku Pengembara Laut. Jakarta: Kepustakaan Populer Gramedia.

Hasan Langgulung. (1986). Manusia dan Pendidikan suatu Analisa Psikologi dan Pendidikan. Jakarta: Al- Husna.

Koentjaraningrat \& Donald K. Emmerson. (1985). Aspek Manusia dalam Penelitian Masyarakat. Jakarta: Gremedia.

Lexy, J. Moleong. (1991). Metodelogy Penelitian Kualitatif. Bandung: Remaja Rosdakarya.

Lincoln, Y. Vonna and Guba, Edger. G. (1985). Naturalistic Inguiry. Beverly Hill Sage Publications.

M. Syahran, dkk. (2013). The Implementation of Five-I Ideology in Learning Process (Study at Elementary School of Fisherman Rural Area of Bajau Ethnic Kuala Tungkal, Jambi Province, Indonesia), International Journal of Education and Research.ISSN: 2201-6333/ISSN: 2201-6740 (Online), Vol.1 No. 7 July 2013. Australia.

(2013). Keberadaan Badan Akreditasi Provinsi Sekolah/Madrasah (BAP S/M) Upaya Meningkatkan Mutu Pendidikan Madrasah di Provinsi Jambi, (Laporan Hasil Penelitian tidak dipublikasikan) DIPA IAIN STS Jambi tahun 2013.

(2014). The Professionalism of Certified Teachers in Intructional Process: A Case Study of Secondary School Teachers in Jambi. Al-Ta"lim Journal. ISSN: 14107546 e-ISSN: 2355-7893. Vol. 21 Number 2. July 2014.Padang.

Mubyarto Dkk. (1984). Nelayan dan kemiskinan. Jakarta: Rajawali

Muhaimin. (2009). Rekonstruksi Pendidikan Islam. Jakarta: Raja Grafindo

Muhaimin dan Abdul Mujib. (1993) Pemikiran pendidikan Islam Kajian Filosofis dan Kerangka Dasar Operasionalisasinya. Bandung: Trigenda Karya.

Novak, Joseph D. (1986). A Theory of Education. London: Cornell University Press..

Prosiding Seminar Internasional, (2015) Kesiapan Pendidikan Islam Memasuki Masyarakat Ekonomi ASEAN (MEA) 2015. ISBN 978-602-73772-0-2. Penerbit Fakultas Ilmu Tarbiyah dan Keguruan IAIN Sulthan Thaha Jambi 


\section{MADRASAH}

Jurnal Pendidikan dan Pembelajaran Dasar

p ISSN: 1979-5599 | e ISSN: 2502-194X

P a g e | 167

Samsul Nizar. (2009). Sejarah Pendidikan Islam Menelusuri Jejak Sejarah Pendidikan Era Rasulullah samai Indonesia.Jakarta: Kencana Predana Media.

Soetomo. (2009). Pembangunan Masyarakat Merangkai Sebuah Kerangka. Yogyakarta: Pustaka Pelajar.

Subiyantoro. (2003). Pengembangan Model Pendidikan Nilai Humanis-Relegius Berbasis Kultul Madrasah, dalam Jurnal Cakrawala Pendidikan. ISSN 0216-1370, November 2013. XXXII, No. 3

Spradley, James. P. (1980) Participan Observation.United state of America: Rinehart and winston.

(1997). Metode Etnografi (terjemahan Misbah Elizabeth). Yogyakarta: Tiara Wacana.

Toto Suharto.(2005). Konsep Dasar Pendidikan Berbasis Masyarakat, dalam Jurnal Cakrawala Pendidikan. ISSN: 0216-1370, November 2005. XXIV, No. 3. (Hal: 329).

Undang-undang Sistem Penddikan Nasional Nomor 20 Tahun 2003. Jakarta: Penerbit Harvarindo.

Peraturan Pemerintah Nomor 19 Tahun 2005 tentang Standar Nasional Pendidikan.

Peraturan Mendiknas Nomor 29 Tahun 2005 tentang Badan Akreditasi Nasional Sekolah/Madrasah.

Surat Edaran Dirjen Pendidikan Islam Nomor SE. DJ.l/PP.00/05/2008 tentang Akreditasi Madrasah.

Van Scotter, D. Richard, Kraft, J. Richard, Haas, D. John. (1979). Foundations of Education Social Perspectives. United States of America: Englewood Cliffs.

Winarno Surakhmad, (2009). Pendidikan Nasional Strategi dan Tragedi. Jakarta: Kompas. 